\title{
Levels of essential and toxic metals in fenugreek seeds (Trigonella Foenum-Graecum L.) cultivated in different parts of Ethiopia
}

\author{
Niveis de metais essenciais e tóxicos em sementes de fenacho \\ (Trigonella Foenum-Graecum L.) cultivados em diferentes partes de Etiópia
}

\author{
Mebrahtu Hagos ${ }^{1}$, Bhagwan Singh Chandravanshi ${ }^{1 *}$ \\ ${ }^{1}$ Addis Ababa University, Department of Chemistry, Addis Ababa - Ethiopia \\ *Corresponding Author \\ Bhagwan Singh Chandravanshi, Addis Ababa University, Department of Chemistry, P. O. Box: 1176, Addis Ababa - Ethiopia, e-mail: bscv2006@yahoo.com
}

Cite as: Levels of essential and toxic metals in fenugreek seeds (Trigonella Foenum-Graecum L.) cultivated in different parts of Ethiopia. Braz. J. Food Technol., v. 19, e2015059, 2016.

Received: July 16, 2016; Accepted: Sept. 20, 2016

\section{Summary}

The levels of the major ( $\mathrm{Ca}, \mathrm{K}, \mathrm{Na}, \mathrm{Mg}$ ), trace ( $\mathrm{Fe}, \mathrm{Cr}, \mathrm{Ni}, \mathrm{Zn}, \mathrm{Mn}, \mathrm{Cu}, \mathrm{Co}$ ), and toxic ( $\mathrm{Pb}, \mathrm{Cd}$ ) metals in the seeds of fenugreek cultivated in different regions of Ethiopia were determined by flame atomic absorption spectrophotometry (FAAS). Wet ashing was used to digest $0.5 \mathrm{~g}$ of fenugreek seed flour using $1.5 \mathrm{~mL}$ of $\mathrm{HNO}_{3}$ and $\mathrm{HClO}_{4}$ acid mixtures (5:1 ratio), $30 \mathrm{~min}$ pre-digestion time, $45 \mathrm{~min}$ total digestion time and a temperature of $150^{\circ} \mathrm{C}$. Thirteen elements were determined, obtaining concentrations in the following ranges: $\mathrm{Ca}\left(15353-36771 \mathrm{mg} \mathrm{kg}^{-1}\right)>\mathrm{Fe}\left(6041-18584 \mathrm{mg} \mathrm{kg}^{-1}\right) \approx \mathrm{K}\left(6789-11517 \mathrm{mg} \mathrm{kg}^{-1}\right)>$ $\mathrm{Pb}\left(615-2624 \mathrm{mg} \mathrm{kg}^{-1}\right)>\mathrm{Na}\left(201-1559 \mathrm{mg} \mathrm{kg}^{-1}\right)>\mathrm{Cd}\left(285-464 \mathrm{mg} \mathrm{kg}^{-1}\right)>\mathrm{Cr}\left(3-552 \mathrm{mg} \mathrm{kg}^{-1}\right)>\mathrm{Ni}\left(31-108 \mathrm{mg} \mathrm{kg}^{-1}\right)>\mathrm{Mg}$ $\left(31-102 \mathrm{mg} \mathrm{kg}^{-1}\right)>\mathrm{Zn}\left(15-33 \mathrm{mg} \mathrm{kg}^{-1}\right)>\mathrm{Mn}\left(16-28 \mathrm{mg} \mathrm{kg}^{-1}\right)>\mathrm{Cu}\left(\mathrm{ND}-35 \mathrm{mg} \mathrm{kg}^{-1}\right)>\mathrm{Co}\left(4-15 \mathrm{mg} \mathrm{kg}^{-1}\right)$. A statistical analysis of variance (ANOVA) at the $95 \%$ confidence level revealed there were significant differences between the mean metal contents of fourteen sample means, except for Zn. Pearson's correlation revealed weak positive or negative linear relationships, which implies that the presence of one metal did not affect the presence of the other metals within the plant, except for a few metals. The study showed that fenugreek seeds were a good source of essential metals. However, they also contained large amounts of the toxic metals $\mathrm{Cd}$ and $\mathrm{Pb}$ and therefore should not be consumed daily.

Keywords: Fenugreek seed; Trigonella foenum-graecum L.; Major elements; Trace elements; Toxic elements; Ethiopia; Flame atomic absorption spectrophotometry.

\section{Resumo}

Os níveis dos metais majoritários ( $\mathrm{Ca}, \mathrm{K}, \mathrm{Na}, \mathrm{Mg}$ ), traços ( $\mathrm{Fe}, \mathrm{Cr}, \mathrm{Ni}, \mathrm{Zn}, \mathrm{Mn}, \mathrm{Cu}, \mathrm{Co}$ ) e tóxicos (Pb, Cd) nas sementes de fenacho, cultivadas em regiões diferentes de Etiópia, foram determinados por espectrofotometria de absorção atómica com chama (EAAC). A incineração á úmido foi usada para digerir $0,5 \mathrm{~g}$ da farinha das sementes de fenacho, usando 1,5 $\mathrm{mL}$ de uma mistura dos ácidos $\mathrm{HNO}_{3}$ e $\mathrm{HClO}_{4}$ (relação de 5:1), com 30 min de digestão prévia, 45 min de digestão total a temperatura de $150^{\circ} \mathrm{C}$. Treze elementos foram determinados, obtendo-se concentrações nas seguintes faixas: $\mathrm{Ca}\left(15353-36771 \mathrm{mg} \mathrm{kg}^{-1}\right)>\mathrm{Fe}$ $\left(6041-18584 \mathrm{mg} \mathrm{kg}^{-1}\right) \approx \mathrm{K}\left(6789-11517 \mathrm{mg} \mathrm{kg}^{-1}\right)>\mathrm{Pb}\left(615-2624 \mathrm{mg} \mathrm{kg}^{-1}\right)>\mathrm{Na}\left(201-1559 \mathrm{mg} \mathrm{kg}^{-1}\right)>\mathrm{Cd}\left(285-464 \mathrm{mg} \mathrm{kg}^{-1}\right)>\mathrm{Cr}$ $\left(3-552 \mathrm{mg} \mathrm{kg}^{-1}\right)>\mathrm{Ni}\left(31-108 \mathrm{mg} \mathrm{kg}^{-1}\right)>\mathrm{Mg}\left(31-102 \mathrm{mg} \mathrm{kg}^{-1}\right)>\mathrm{Zn}\left(15-33 \mathrm{mg} \mathrm{kg}^{-1}\right)>\mathrm{Mn}\left(16-28 \mathrm{mg} \mathrm{kg}^{-1}\right)>\mathrm{Cu}\left(\mathrm{ND}-35 \mathrm{mg} \mathrm{kg}^{-1}\right)$ $>$ Co (4-15 mg kg-1). Uma análise estatística de variância (ANOVA), a nível de confiança de 95\%, revelou que houve diferenças significativas entre os teores médios dos metais das quatorze amostras, exceto para Zn. A correlação de Pearson revelou relações lineares fracamente positivas ou negativas, o que implica que a presença de um metal não afeta a presença de outros metais dentro da planta, com exceção de alguns metais. $\mathrm{O}$ estudo demonstrou que as sementes de fenacho são uma boa fonte dos metais essenciais. Contudo, também continham quantias grandes dos metais tóxicos $\mathrm{Cd}$ e Pb e, portanto, não devem ser consumidas diariamente.

Palavras-chave: Sementes de fenacho; Trigonella foenum-graecum L.; Elementos majoritários; Oligoelementos; Elementos tóxicos; Etiópia; Espectrofotometria de absorção atómica com chama. 
Hagos, M.; Chandravanshi, B. S.

\section{Introduction}

Trigonella foenum-graecum (fenugreek) is native to Ethiopia and to the area from the Eastern Mediterranean to Central Asia, and is widely cultivated in Pakistan, India and China (ZIA et al., 2003; BEKELE, 2007; CHANDRASHEKHAR; KHADSE, 2010). Its common English name is fenugreek and its vernacular names in the different regions of Ethiopia are Abake (Tigrigna), Abeshe (Guraginga), Abish (Amharic and Kore), Abishi or Sunqoo (Afan Oromo), Sets (Bas), Shiko (Sid), Shuko (Gam) and Shuqwa (Konta, wel) (AHARI et al., 2009). The genus Trigonella is one of the largest genera of the tribe Trifoliatae in the family Fabaceae and sub-family Papilionaceae (MARZOUGUI et al., 2009). Fenugreek seeds contain about $50 \%$ fibre and also contain protein, saponins and the hypoglycemic phytochemicals coumarin, fenugreekine, nicotinic acid, phytic acid, scopoletin and trigonelline (ASFAW; DEMISSEW, 2009; HEDBERG; EDWARDS, 1989; FATIMA et al., 2005) and 4-hydroxyisoleucine (HEDBERG; EDWARDS, 1989). Fenugreek seeds have high contents of iron, calcium, zinc (LEIGH BROADHURST, 1997), lysins and $\beta$-carotene (EFSA, 2010) and are a rich source of flavonoid compounds such as quercetin, luteolin, kaempferol, tricin and gallic acid. Many workers have reported the antioxidant potential of fenugreek (EIBEN et al., 2004).

Fenugreek leaves and seeds are consumed in different countries around the world for different purposes, such as medicinal uses (anti-diabetic, lowering the blood sugar and cholesterol levels, anti-cancer, anti-microbial, against breast cancer (IBRAHIUM; HEGAZY, 2009), avoiding blood poisoning from wounds (HOODA; JOOD, 2005), making food (stew with rice in Iran, flavouring cheese in Switzerland, syrup and bitter rum in Germany, mixed seed powder with flour for making flat bread in Egypt, curries, dyes, young seedlings for eating as a vegetable), roasted grain as a coffee-substitute (in Africa), controlling insects in grain storages and perfume industries. The seeds of this ancient herb have been used as both a spice and a herbal remedy in the Middle East, India, and Egypt and later on in Europe, China and other parts of the world (SUSHMA; DEVASENA, 2010). Fenugreek seeds have been reported for their pharmaceutical properties in treating such human diseases as diabetes and hypercholesterolemia (ZIA et al., 2003).

In Ethiopia fenugreek is cultivated between altitudes of 1600 and $2300 \mathrm{~m}$ above sea level all over the country (AHARI et al., 2009) and is used in preparing "Hilbet", a delicious, traditional, soft white food in the Tigray regional state. It is also used to make tea, "Enjera", flat bread mostly made of "tef" flour, as a spice in milk and in traditional medicine.

Recently some studies have been carried out on the mineral composition of selected spices (thyme, fennel, ginger, korarima, and red pepper) cultivated in
Ethiopia (DERBIE; CHANDRAVANSHI, 2011; ENDALAMAW; CHANDRAVANSHI, 2015; WAGESHO; CHANDRAVANSHI, 2015; MEKASSA; CHANDRAVANSHI, 2015; TEFERA; CHANDRAVANSHI, 2016). Several global studies were also been done on Trigonella foenum-graecum (fenugreek) especially in the areas of medicine and to determine the metal content. However, none of these studies were done in Ethiopia. Therefore, it seemed worthwhile to study the levels of essential and non-essential metals in T. foenum-graecum (fenugreek) cultivated in Ethiopia. The assessment of the major metals ( $\mathrm{Ca}, \mathrm{K}, \mathrm{Na}$ and $\mathrm{Mg}$ ), trace metals (Fe, $\mathrm{Cr}, \mathrm{Ni}, \mathrm{Zn}, \mathrm{Mn}, \mathrm{Cu}, \mathrm{Co}$ ) and toxic metals (Pb, Cd) in T. foenum-graecum (fenugreek) samples collected from the Amhara and Tigray regional states of Ethiopia was carried out in order to produce experimental data which could be used to identify the nutritional use as well as the toxicological status of the spice. It was also considered helpful to determine the sources of the metals and to assess the pollution level.

The main objective of this study was (i) to determine the levels of the major ( $\mathrm{Ca}, \mathrm{K}, \mathrm{Na}, \mathrm{Mg}$ ), trace ( $\mathrm{Fe}, \mathrm{Cr}, \mathrm{Ni}$, $\mathrm{Zn}, \mathrm{Mn}, \mathrm{Cu}, \mathrm{Co}$ ), and toxic (Pb, Cd) metals in Trigonella foenum-graecum L. (fenugreek) cultivated in Ethiopia using flame atomic absorption spectrophotometry (FAAS), (ii) to compare the levels of the metals in fenugreek seeds from different regions of Ethiopia with that of the data in the literature, and (iii) to compare the levels of the metals in fenugreek seeds with that of the data on other spices, available in the literature.

\section{Materials and methods}

\subsection{Apparatuses}

A Gallenkamp Kjeldahl apparatus (UK) was used to digest the fenugreek samples. A flame atomic absorption spectrophotometer (Buck Scientific Model 210 VGP AAS, East Norwalk, USA) using a deuterium background corrector with an air-acetylene flame was used to determine the concentrations of the metals $\mathrm{Ca}, \mathrm{K}, \mathrm{Na}, \mathrm{Mg}, \mathrm{Fe}, \mathrm{Cr}, \mathrm{Ni}$, $\mathrm{Zn}, \mathrm{Mn}, \mathrm{Cu}, \mathrm{Co}, \mathrm{Pb}$, and $\mathrm{Cd}$ in the fenugreek samples.

\subsection{Reagents}

All the chemicals and reagents used were of analytical grade. Sulfuric acid $98 \%, \mathrm{H}_{2} \mathrm{SO}_{4}$ (Fine Chem, Mumbai, India), perchloric acid $70 \%, \mathrm{HClO}_{4}$ (Fine Chem, Mumbai, India), hydrogen peroxide, 30\%, w/w, extra pure (Spain), nitric acid, $\mathrm{HNO}_{3}$ (pure 69-72\%) (Spectrol, $\mathrm{BDH}$, England) were used for the digestion of the fenugreek seed samples. Standard solutions (1000 $\mathrm{mg} / \mathrm{L}$ in $2 \% \mathrm{HNO}_{3}$ ) of $\mathrm{Ca}, \mathrm{K}, \mathrm{Na}, \mathrm{Mg}, \mathrm{Fe}, \mathrm{Cr}, \mathrm{Ni}, \mathrm{Zn}, \mathrm{Mn}, \mathrm{Cu}, \mathrm{Co}, \mathrm{Pb}$, and $\mathrm{Cd}$ (Buck Scientific Puro-Graphic ${ }^{\mathrm{tm}}$ ) were used to prepare the calibration curves. $\mathrm{LaNO}_{3} \cdot 6 \mathrm{H}_{2} \mathrm{O}(98 \%$, Aldrich, USA) solution was used to prevent chemical interference from phosphates and other anions in the measurements of $\mathrm{Ca}$ 
Levels of essential and toxic metals in fenugreek seeds (Trigonella Foenum-Graecum L.) cultivated in different parts of Ethiopia

Hagos, M.; Chandravanshi, B. S.

and Mg. Chemically pure deionized water (with electrical conductivity $<2 \mu \mathrm{sm}^{-1}$ ) was used for cleaning the digestion and volumetric flasks and to dilute the samples.

\subsection{Sample collection}

Sample sites were selected in both the Amhara and Tigray regional states, based on the wider cultivation of the plant in these regions of the country. Fourteen sample sites were selected in this study as follows: Donbeskie, Koladiba, Ambagiorgis and Dabat (North Gonder, Ahmara region), Johaniagiorgis (West Gojam, Ahmara region), Adet and Bichena (East Gojam, Ahmara region), Keteteekli, Mayadrasha, Edagaarbi and Hatsebo (Central Tigray, Tigray region), Meseretgamra and Korem (Southern Tigray, Tigray region), Debrebirhan (North Shewa, Ahmara region).

Fenugreek seeds were collected from the different parts of the Amhara and Tigray regional states of Ethiopia. They were bought from the corresponding local markets from peasants living in that area. Half a kilogram was bought at most sample sites, packed into clean, dry polyethylene plastic bags, and finally transported to the Chemistry Department of the Science Faculty of Addis Ababa University for further study.

\subsection{Sample preparation}

The fenugreek seeds samples were washed with deionized water and then allowed to sundry in the open air. Each sample was then oven dried at $80{ }^{\circ} \mathrm{C}$ for $24 \mathrm{~h}$. The dried samples were ground in a stainless steel blender (Moulindex, France) and the flour allowed to pass through a $1.4 \mathrm{~mm}$ mesh and kept in clean labelled plastic bags.

\subsection{Optimization of the digestion procedure}

There are several different methods to decompose organic samples using inorganic acids in an open vessel, and one of these is wet ashing. Wet ashing is the oxidative decomposition of organic samples by liquid oxidizing reagents such as $\mathrm{HNO}_{3}, \mathrm{H}_{2} \mathrm{SO}_{4}, \mathrm{HClO}_{4}$ or mixture of these acids. This decomposition process converts the organic sample to carbon dioxide and water. Non-metallic elements such as halogens, sulfur and nitrogen, are wholly or partially lost by volatilization in an open vessel (SKOOG et al., 1996; SOYLAK et al., 2004).

To optimize the digestion of the fenugreek seed samples, different oxidizing agents and/or acid combinations were tested, using $0.5 \mathrm{~g}$ samples. Three different mixtures: conc. $\mathrm{H}_{2} \mathrm{SO}_{4} / 30 \% \mathrm{H}_{2} \mathrm{O}_{2}$, conc. $\mathrm{H}_{2} \mathrm{SO}_{4} / \mathrm{HNO}_{3} / 30 \% \mathrm{H}_{2} \mathrm{O}_{2}$ and $\mathrm{HNO}_{3} / \mathrm{HClO}_{4}$ were tested. The first and second combinations were not good and only the last combination gave good results. Therefore, to optimize the digestion procedure for fenugreek seeds, different ratios of $\mathrm{HNO}_{3} / \mathrm{HClO}_{4}$ were used and the best result was obtained with a 5:1 ratio. The optimum condition for digestion was found using a total volume of $1.5 \mathrm{~mL}$ of the acid mixtures, temperature of
$150{ }^{\circ} \mathrm{C}, 30$ min pre-digestion time and 45 min total digestion time. The optimization of the digestion procedures for this study was done based on the parameters of time, volume, temperatures and reagent compositions, and the optimized condition was selected based on the criteria of minimum reagent costs, minimum time and a clear solution. Each of the 14 fenugreek seed samples was digested in triplicate.

\subsection{Digestion of the fenugreek seed samples}

A $0.5 \mathrm{~g}$ aliquot of powdered fenugreek seed was transferred to a $100 \mathrm{~mL}$ digestion flask followed by a total volume of $1.5 \mathrm{~mL}$ of the $\mathrm{HNO}_{3} / \mathrm{HClO}_{4}$ acid mixture, i.e. 5:1 ratio. The mixture was allowed to remain in the open air for 30 min pre-digestion time and then digested at $150^{\circ} \mathrm{C}$ for 45 min using a Gallenkamp Kjeldahl apparatus. The sample in the digestion flask was allowed to cool for about 40 min and then filtered through $70 \mathrm{~mm}$ Whatman filter paper into a $50 \mathrm{~mL}$ volumetric flask. $1 \mathrm{~mL}$ of a lanthanum nitrate solution and deionized water were added to the filtrate and then diluted to volume with distilled deionized water. The solution in the volumetric flask was thus ready for further analysis using flame atomic absorption spectrophotometry.

To determine the concentration of metals in the acid mixtures, blank samples were digested in the same manner as the fenugreek seed samples. A total of 10 blanks were prepared and digested.

\subsection{Instrument calibration}

The atomic absorption spectrometer was calibrated using four series of working standards. The working standard solutions of each metal were prepared freshly by diluting the intermediate standard solutions. A $10 \mathrm{mg} \mathrm{L}^{-1}$ intermediate standard solution of each metal was prepared by diluting a $1000 \mathrm{mg} \mathrm{L}^{-1}$ stock standard solution. The solution thus prepared was used to calibrate the instrument before determining the metal concentrations in the samples.

\subsection{Method detection limit}

A very important quantity in chemical analysis is the limit of detection. The LOD is the smallest concentration or amount that can be detected with reasonable certainty by a given analytical procedure (ENKE, 2000). In this study, the method detection limit of each element was calculated as three times the standard deviation of the blank $(n=10)$. The method detection limits were found to be low enough $\left(<0.1 \mathrm{mg} \mathrm{kg}^{-1}\right)$ to detect the trace quantities of selected metals in the fenugreek seed samples.

\subsection{Precision and accuracy}

The errors in analytical results can be expressed in terms of accuracy and precision (SKOOG et al., 1996). In this study the precision of the results was evaluated from 
Levels of essential and toxic metals in fenugreek seeds (Trigonella Foenum-Graecum L.) cultivated in different parts of Ethiopia

Hagos, M.; Chandravanshi, B. S.

the standard deviation of triplicate samples with triplicate measurements of each sample $(n=9)$, while the accuracy and the validity of the analytical method were determined by spiking the samples with known concentrations of standard solution.

\subsection{Method validation}

The efficiency of the optimized procedure was checked by spiking a known concentration of analyte into the sample. In this study $20 \%$ of the metal concentration determined was first spiked into the sample, and then digested in the same way as the un-spiked sample. The spiked concentrations of these metals were 0.307 , 13.6, 0.906, 30.7, 23.1, 0.35, 0.13, 0.06, 0.056, 0.05, 0.03, 1.8 and $0.6 \mathrm{mg} \mathrm{L}^{-1}$ for $\mathrm{Ca}, \mathrm{K}, \mathrm{Na}, \mathrm{Mg}, \mathrm{Fe}, \mathrm{Cr}, \mathrm{Ni}, \mathrm{Zn}, \mathrm{Mn}$, $\mathrm{Cu}, \mathrm{Co}, \mathrm{Pb}$ and $\mathrm{Cd}$, respectively. $50 \mu \mathrm{L}$ each of $\mathrm{Na}, \mathrm{Fe}, \mathrm{Ni}$, $\mathrm{Mn}, \mathrm{Cu}, \mathrm{Co}$ and $\mathrm{Pb}$ were spiked into one $100 \mathrm{~mL}$ digestion flask containing $0.5 \mathrm{~g}$ of fenugreek seed sample, and $50 \mu \mathrm{L}$ each of $\mathrm{Ca}, \mathrm{K}, \mathrm{Mg}, \mathrm{Cr}, \mathrm{Zn}$ and $\mathrm{Cd}$ were spiked into another flask and digested using the optimized digestion procedure. Both the spiked and non-spiked samples were digested and analysed under similar conditions. Finally the percent recovery ( $\% R$ ) of the analyte was calculated. The percent recoveries were found to be in the range from $94-109 \%$, which is within the acceptable range.

\section{Results and discussion}

\subsection{Distribution pattern of the metals in fenugreek samples from the different sampling sites}

The concentrations of thirteen metals ( $\mathrm{Ca}, \mathrm{K}, \mathrm{Na}, \mathrm{Mg}$, $\mathrm{Fe}, \mathrm{Cr}, \mathrm{Ni}, \mathrm{Zn}, \mathrm{Mn}, \mathrm{Cu}, \mathrm{Co}, \mathrm{Pb}$ and $\mathrm{Cd}$ ) were determined by digesting fenugreek seed flour and analysing by flame atomic absorption spectrometry, and the results are given in Table 1. The most abundant major element in fenugreek seed was $\mathrm{Ca}$, the main trace element Fe and the major toxic element $\mathrm{Pb}$. The concentrations of the major elements, i.e. $\mathrm{Ca}, \mathrm{K}, \mathrm{Na}$ and $\mathrm{Mg}$ in the fenugreek seed samples were found in the ranges from $1553-36771 \mathrm{mg} \mathrm{kg}^{-1}$, 6789-11517 $\mathrm{mg} \mathrm{kg}^{-1}, 201-1559 \mathrm{mg} \mathrm{kg}^{-1}$ and 31-102 $\mathrm{mg} \mathrm{kg}^{-1}$; respectively. The concentrations of the trace elements, i.e. $\mathrm{Fe}, \mathrm{Cr}, \mathrm{Ni}, \mathrm{Zn}, \mathrm{Mn}, \mathrm{Cu}$ and $\mathrm{Co}$ were found in the ranges from 6041-18585 mg kg-1 , 3-552 mg kg ${ }^{-1}, 31-108 \mathrm{mg} \mathrm{kg}^{-1}, 15-33$ $\mathrm{mg} \mathrm{kg}^{-1}$, 16-28 $\mathrm{mg} \mathrm{kg}^{-1}$, N.D-35 mg kg-1 and 4-15 mg kg-1; respectively. Finally the concentrations of the toxic metals $\mathrm{Pb}$ and $\mathrm{Cd}$ were found in the ranges from 615-1814 $\mathrm{mg} \mathrm{kg}^{-1}$ and 285-464 $\mathrm{mg} \mathrm{kg}^{-1}$; respectively. Of the trace elements $\mathrm{Fe}$, had the highest concentration due to the relatively higher Fe contents in Ethiopian soils. To the contrary, of the major plant elements, Mg was the metal with the lowest concentration. This may be due to the plant having a greater affinity for metals other than $\mathrm{Mg}$. However, unlike other spices studied in Ethiopia, the concentrations of the toxic metals $\mathrm{Pb}$ and $\mathrm{Cd}$ were found to be much higher in the fenugreek seeds. The sources of these concentrations could be from the soil where the plants were cultivated or from the fertilizers used by the farmers.

The metal contents in the fenugreek seeds were found in the following decreasing order: $\mathrm{Ca}>\mathrm{Fe} \approx \mathrm{K}>\mathrm{Pb}>$ $\mathrm{Na}>\mathrm{Cd}>\mathrm{Cr}>\mathrm{Ni}>\mathrm{Mg}>\mathrm{Zn}>\mathrm{Mn}>\mathrm{Cu}>\mathrm{Co}$. Mineral uptake in plants is a function of the mineral concentrations in the soils, soil pH, cation exchange capacity, organic matter content, types and varieties of plants and age of the plant. The reason why the Ca concentration was very high in the fenugreek seeds at all the sample sites may be due to the presence of the thick mesozoic limestone and gypsum sequences in the Blue Nile river area in central Ethiopia, and the proterozoic marbles that occur in northern (Tigray) and western (Gojam) Ethiopia. The marble and limestone could be the main sources of $\mathrm{Ca}$ in the soil from these sample areas. Moreover, $\mathrm{Ca}$ is amongst the major elements required by plants. In the above series, the concentration of $\mathrm{K}$ is higher than that of $\mathrm{Na}$, since plants generally have higher K than Na contents (DEMAN, 1999). Trace elements are ubiquitous in our environment and are found in all the foods we eat. In general, the abundance of trace elements in foods is related to their abundance in the environment and the most abundant trace element in the soil is Fe. In this study Fe was the trace element found in the highest concentration. Similarly, as many authors have mentioned, the Ethiopian soil is rich in Fe minerals, e.g. hematite $\left(\mathrm{Fe}_{2} \mathrm{O}_{3}\right)$, and this may be the reason why the Ethiopian fenugreek seeds are rich in iron contents. However trace elements can get into foods by different pathways. The most important source is from the soil, but they can also be absorbed in aqueous solution through the roots. Another minor source is foliar penetration (industrial air pollution and vehicle emissions) and other possible sources are fertilizers, agricultural chemicals and sewage sludge (DEMAN, 1999).

\subsection{Comparison of the metal levels between the sample sites}

Of the thirteen elements analysed in the fenugreek seeds in this study, Ca showed the highest concentration. The mean concentration of Ca in this study was $26364 \mathrm{mg} \mathrm{kg}^{-1}$, and the highest Ca concentration $\left(36771 \pm 1938 \mathrm{mg} \mathrm{kg}^{-1}\right.$ of dry mass of fenugreek seed) was recorded in the sample from the Edagaarbi site. The three sample sites with the highest Ca concentrations were Edagaarbi, Denboskie and Koladiba, with concentrations of $36771 \pm 1938 \mathrm{mg} \mathrm{kg}^{-1}$, $36085 \pm 1434 \mathrm{mg} \mathrm{kg}^{-1}$ and $32612 \pm 770 \mathrm{mg} \mathrm{kg}^{-1}$, respectively and that with the lowest $\mathrm{Ca}$ concentration was Hatsebo, with $15353 \pm 1758 \mathrm{mg} \mathrm{kg}^{-1}$. The RDA and RDI for Ca for people in the 25-50 year age range are $800 \mathrm{mg}$ per day and 1000 mg per day, respectively (WARDLAW, 1997). The three sample sites with the highest $\mathrm{K}$ concentrations per dry mass were Debrebirhan, Edagaarbi and Mayadrasha, with concentrations of $11517 \pm 294 \mathrm{mg} \mathrm{kg}^{-1}, 10807 \pm 375 \mathrm{mg} \mathrm{kg}^{-1}$ 
Levels of essential and toxic metals in fenugreek seeds (Trigonella Foenum-Graecum L.) cultivated in different parts of Ethiopia

Hagos, M.; Chandravanshi, B. S.

Table 1. Concentrations (mean $\pm \mathrm{SD}, \mathrm{n}=3, \mathrm{mg} \mathrm{kg}^{-1}$ of dry mass) of the major, trace and toxic metals in fenugreek seeds from the different sample sites in Ethiopia.

\begin{tabular}{|c|c|c|c|c|c|c|}
\hline No. & Sample site & $\mathrm{Ca}$ & K & $\mathrm{Na}$ & Mg & $\mathrm{Fe}$ \\
\hline 1 & Denboskie & $36085 \pm 1434$ & $7478 \pm 83$ & $942 \pm 17$ & $74 \pm 4$ & $17807 \pm 1109$ \\
\hline 2 & Koladiba & $32612 \pm 770$ & $9618 \pm 160$ & $201 \pm 6$ & $31 \pm 5$ & $12854 \pm 540$ \\
\hline 3 & Ambagiorgis & $23374 \pm 773$ & $7788 \pm 94$ & $286 \pm 9$ & $99 \pm 2$ & $8216 \pm 1321$ \\
\hline 4 & Dabat & $23350 \pm 2400$ & $9845 \pm 64$ & $529 \pm 21$ & $86 \pm 4$ & $14669 \pm 1395$ \\
\hline 5 & Jehaniagiorgis & $32454 \pm 3701$ & $8534 \pm 67$ & $699 \pm 7$ & $51 \pm 5$ & $15492 \pm 1928$ \\
\hline 6 & Keteteekli & $26194 \pm 1618$ & $7582 \pm 123$ & $442 \pm 9$ & $55 \pm 4$ & $6041 \pm 745$ \\
\hline 7 & Adet & $16443 \pm 1521$ & $9354 \pm 136$ & $578 \pm 4$ & $67 \pm 6$ & $17318 \pm 1049$ \\
\hline 8 & Bichena & $24114 \pm 1154$ & $9314 \pm 78$ & $452 \pm 14$ & $96 \pm 5$ & $15690 \pm 920$ \\
\hline 9 & Meseretgamra & $23900 \pm 1326$ & $9206 \pm 211$ & $1559 \pm 41$ & $42 \pm 7$ & $12493 \pm 919$ \\
\hline 10 & Mayadrasha & $27113 \pm 2480$ & $10451 \pm 220$ & $1156 \pm 5$ & $57 \pm 6$ & $18584 \pm 1339$ \\
\hline 11 & Edagaarbi & $36771 \pm 1938$ & $10807 \pm 375$ & $1172 \pm 6$ & $96 \pm 5$ & $15378 \pm 945$ \\
\hline 12 & Hatsebo & $15353 \pm 1896$ & $6789 \pm 88$ & $453 \pm 10$ & $44 \pm 3$ & $11560 \pm 1355$ \\
\hline 13 & Debrebirhan & $22433 \pm 3115$ & $11517 \pm 294$ & $415 \pm 10$ & $69 \pm 5$ & $16104 \pm 2307$ \\
\hline \multirow[t]{3}{*}{14} & Korem & $28903 \pm 3138$ & $9401 \pm 155$ & $1532 \pm 12$ & $102 \pm 6$ & $14870 \pm 1327$ \\
\hline & Mean & 26364 & 8448 & 744 & 69 & 14077 \\
\hline & Range & $15353-36771$ & 6789-11517 & 201-1559 & $31-102$ & 6041-18584 \\
\hline No. & Sample site & $\mathrm{Cr}$ & $\mathrm{Ni}$ & $\mathrm{Zn}$ & Mn & \\
\hline 1 & Denboskie & $275 \pm 16$ & $34 \pm 4$ & $33.0 \pm 0.3$ & $16.0 \pm 0.4$ & \\
\hline 2 & Koladiba & $552 \pm 9$ & $89 \pm 9$ & $27.0 \pm 0.3$ & $18.0 \pm 0.5$ & \\
\hline 3 & Ambagiorgis & $170 \pm 13$ & $117 \pm 16$ & $27 \pm 0.5$ & $20.0 \pm 0.8$ & \\
\hline 4 & Dabat & $419 \pm 42$ & $115 \pm 5$ & $28 \pm 0.4$ & $16.0 \pm 0.3$ & \\
\hline 5 & Jehaniagiorgis & $279 \pm 17$ & $108 \pm 12$ & $16.0 \pm 0.6$ & $20.0 \pm 0.6$ & \\
\hline 6 & Keteteekli & $388 \pm 16$ & $31 \pm 5$ & $21.0 \pm 0.5$ & $19.0 \pm 0.4$ & \\
\hline 7 & Adet & $339 \pm 29$ & $107 \pm 5$ & $17.0 \pm 0.4$ & $18.0 \pm 0.5$ & \\
\hline 8 & Bichena & $283 \pm 24$ & $52 \pm 3$ & $15.0 \pm 0.7$ & $19.0 \pm 0.6$ & \\
\hline 9 & Meseretgamra & $74 \pm 10$ & $99 \pm 10$ & $17.0 \pm 0.2$ & $16.0 \pm 0.5$ & \\
\hline 10 & Mayadrasha & $279 \pm 10$ & $73 \pm 2$ & $24.0 \pm 0.3$ & $22 \pm 0.8$ & \\
\hline 11 & Edagaarbi & $242 \pm 14$ & $97 \pm 7$ & $18 \pm 1.1$ & $18 \pm 2$ & \\
\hline 12 & Hatsebo & $175 \pm 13$ & $67 \pm 5$ & $30 \pm 0.2$ & $28 \pm 0.8$ & \\
\hline 13 & Debrebirhan & $413 \pm 37$ & $41 \pm 3$ & $22 \pm 0.2$ & $21.0 \pm 0.7$ & \\
\hline \multirow[t]{3}{*}{14} & Korem & $3.0 \pm 0.5$ & $101 \pm 9$ & $23 \pm 0.2$ & $19.0 \pm 0.7$ & \\
\hline & Mean & 278 & 81 & 23 & 19 & \\
\hline & Range & 3-552 & $31-108$ & $15-33$ & $16-28$ & \\
\hline No. & Sample site & $\mathrm{Cu}$ & Co & $\mathbf{P b}$ & Cd & \\
\hline 1 & Denboskie & $25 \pm 0.8$ & $9.0 \pm 1.1$ & $1220 \pm 16$ & $318 \pm 12$ & \\
\hline 2 & Koladiba & $5.0 \pm 0.4$ & $11.0 \pm 0.2$ & $624 \pm 75$ & $355 \pm 9$ & \\
\hline 3 & Ambagiorgis & $9 \pm 0.5$ & $11 \pm 0.5$ & $615 \pm 75$ & $303 \pm 11$ & \\
\hline 4 & Dabat & $7 \pm 1$ & $10.0 \pm 0.4$ & $559 \pm 36$ & $464 \pm 14$ & \\
\hline 5 & Jehaniagiorgis & ND & $15.0 \pm 0.6$ & $1282 \pm 124$ & $374 \pm 10$ & \\
\hline 6 & Keteteekli & $15 \pm 0.2$ & $4.0 \pm 0.3$ & $1687 \pm 136$ & $396 \pm 10$ & \\
\hline 7 & Adet & $7 \pm 1$ & $7.0 \pm 0.7$ & $785 \pm 42$ & $285 \pm 22$ & \\
\hline 8 & Bichena & $5.0 \pm 0.5$ & $10.0 \pm 0.3$ & $1355 \pm 42$ & $463 \pm 10$ & \\
\hline 9 & Meseretgamra & $14.0 \pm 0.6$ & $10.0 \pm 0.6$ & $2624 \pm 101$ & $285 \pm 32$ & \\
\hline 10 & Mayadrasha & $35 \pm 1$ & $11.0 \pm 0.3$ & $1387 \pm 91$ & $378 \pm 20$ & \\
\hline 11 & Edagaarbi & $35 \pm 1$ & $14.0 \pm 0.7$ & $1776 \pm 145$ & $286 \pm 11$ & \\
\hline 12 & Hatsebo & $26.0 \pm 0.3$ & $15.0 \pm 0.4$ & $1258 \pm 12$ & $312 \pm 12$ & \\
\hline 13 & Debrebirhan & $28 \pm 4$ & $13.0 \pm 0.7$ & $1814 \pm 67$ & $287 \pm 16$ & \\
\hline \multirow[t]{3}{*}{14} & Korem & $16.0 \pm 0.4$ & $10.0 \pm 0.2$ & $1631 \pm 54$ & $311 \pm 17$ & \\
\hline & Mean & 17 & 11 & 1330 & 344 & \\
\hline & Range & ND-35 & $4-15$ & $615-2624$ & $285-464$ & \\
\hline
\end{tabular}


Hagos, M.; Chandravanshi, B. S.

and $10451 \pm 220 \mathrm{mg} \mathrm{kg}^{-1}$, respectively. The site with the lowest $\mathrm{K}$ concentration in the fenugreek seeds was Hatsebo $\left(6789 \pm 155 \mathrm{mg} \mathrm{kg}^{-1}\right)$. The estimated minimum $\mathrm{K}$ requirement for a healthy person above 18 is $2000 \mathrm{mg}$ per day (WARDLAW, 1997). In Canada, the median dietary intake range is from 3.2 to $3.4 \mathrm{~g}$ per day for men and 2.4 to $2.6 \mathrm{~g}$ per day for women (JENNIFER et al., 2006). The three sample sites with the highest $\mathrm{Na}$ concentrations per dry mass were Mesretgamra, Korem and Edagaarbi, with $1559 \pm 41 \mathrm{mg} \mathrm{kg}^{-1}, 1532 \pm 12 \mathrm{mg} \mathrm{kg}^{-1}$ and $1172 \pm 6 \mathrm{mg} \mathrm{kg}^{-1}$, respectively, and the site with the lowest $\mathrm{Na}$ concentration was Koladiba ( $\left.201 \pm 6 \mathrm{mg} \mathrm{kg}^{-1}\right)$. The estimated minimum $\mathrm{Na}$ requirement for a healthy person above 18 is $500 \mathrm{mg}$ per day (WARDLAW, 1997). The Al (Adequate Intake) for $\mathrm{Na}$ for older and elderly adults has been set at $1.3 \mathrm{~g}$ per day for men and women from 50 to 70 years of age, and at $1.2 \mathrm{~g}$ per day for those over 70 (JENNIFER et al., 2006).

The three sample sites with the highest $\mathrm{Mg}$ concentrations were Korem, Ambagiorgis and Bichena with concentrations of $102 \pm 6 \mathrm{mg} \mathrm{kg}^{-1}, 99 \pm 2 \mathrm{mg} \mathrm{kg}^{-1}$ and $96 \pm 5 \mathrm{mg} \mathrm{kg}^{-1}$, respectively, and the site with the lowest $\mathrm{Mg}$ concentration in its fenugreek seeds was Koladiba $\left(31 \pm 4 \mathrm{mg} \mathrm{kg}^{-1}\right)$. The amount of $\mathrm{Mg}$ that can be obtained from fenugreek seeds is very small and hence people are recommended to eat other foods to attain the required amount of $\mathrm{Mg}$.

The three sample sites with the highest $\mathrm{Fe}$ concentrations in their fenugreek seed samples were Mayadrasha, Denboskie and Adet with concentrations of $18584 \pm 1339 \mathrm{mg} \mathrm{kg}^{-1}, 17807 \pm 1109 \mathrm{mg} \mathrm{kg}^{-1}$ and $17318 \pm 1049 \mathrm{mg} \mathrm{kg}^{-1}$, respectively. Conversely, the sample site with the lowest Fe concentration was Keteteekli, with $6041 \pm 745 \mathrm{mg} \mathrm{kg}^{-1}$. The recommended dietary allowance for $\mathrm{Fe}$ for those in the 23-50 year old group is $10 \mathrm{mg}$ per day for men and $18 \mathrm{mg}$ per day for women (WARDLAW, 1997). The Fe concentration determined in fenugreek is very high when compared to the above mentioned values, and therefore people are recommended not to consume this seed regularly. Koladiba, Dabat and Debrebirhan were amongst the sample sites with the highest $\mathrm{Cr}$ concentrations, with values of $552 \pm 9 \mathrm{mg} \mathrm{kg}^{-1}, 419 \pm 42 \mathrm{mg} \mathrm{kg}^{-1}$ and $413 \pm 37 \mathrm{mg} \mathrm{kg}^{-1}$, respectively. The lowest $\mathrm{Cr}$ concentration $\left(3 \pm 0.5 \mathrm{mg} \mathrm{kg}^{-1}\right)$ per dry mass in fenugreek seed was recorded at the Korem site. The Al for $\mathrm{Cr}$ is $35 \mu \mathrm{g}$ per day and $25 \mu \mathrm{g}$ per day, for young men and young women, respectively (EFSA, 2014). In addition to the above, the ESADDIs for Cr for adults is 50-200 $\mu \mathrm{g}$ per day (WARDLAW, 1997). Fenugreek seed is rich in $\mathrm{Cr}$, and should therefore not be taken daily in large quantities, so as to minimize the risk of $\mathrm{Cr}$ contamination. The three sample sites with the highest Ni concentrations were Ambagiorgis, Dabat and Jehaniagiorgis with concentrations of $117 \pm 15 \mathrm{mg} \mathrm{kg}^{-1}$, $115 \pm 5 \mathrm{mg} \mathrm{kg}^{-1}$ and $108 \pm 12 \mathrm{mg} \mathrm{kg}^{-1}$, respectively, and that with the lowest Ni concentration was Keteteekli $\left(31 \pm 5 \mathrm{mg} \mathrm{kg}^{-1}\right)$. The adequate intake of $\mathrm{Ni}$ for people above the age of 19 is $2.3 \mathrm{mg}$ per day for males and $1.8 \mathrm{mg}$ per day for females (JENNIFER et al., 2006).

The three sample sites with the highest $\mathrm{Zn}$ concentrations were Denboskie, Hatsebo and Dabat with the following concentrations: $33 \pm 0.3 \mathrm{mg} \mathrm{kg}^{-1}, 30 \pm 0.2 \mathrm{mg} \mathrm{kg}^{-1}$ and $28 \pm 0.4 \mathrm{mg} \mathrm{kg}^{-1}$, respectively, and that with the lowest Zn concentration was Bichena $\left(15 \pm 0.7 \mathrm{mg} \mathrm{kg}^{-1}\right)$. The ESADDIs and RDA for $Z n$ for people in the age range from 25-50 is $15 \mathrm{mg}$ per day (WARDLAW, 1997). The three sample sites with the highest Mn concentrations per dry mass were Hatsebo, Mayadrasha and Debrebirhan with concentrations of $28 \pm 0.8 \mathrm{mg} \mathrm{kg}^{-1}, 22 \pm 0.8 \mathrm{mg} \mathrm{kg}^{-1}$ and $21 \pm 0.7 \mathrm{mg} \mathrm{kg}^{-1}$, respectively, and the lowest $\mathrm{Mn}$ concentrations were recorded in Meseretgamra, Dabat and Denboskie $\left(16 \pm 0.5 \mathrm{mg} \mathrm{kg}^{-1}, 16 \pm 0.3 \mathrm{mg} \mathrm{kg}^{-1}\right.$ and $16 \pm 0.4 \mathrm{mg} \mathrm{kg}^{-1}$, respectively). For adults, the estimated safe and adequate daily dietary intake (ESADDIS) for $\mathrm{Mn}$ is from 2-5 mg per day (WARDLAW, 1997).

The sample sites with the highest $\mathrm{Cu}$ concentrations were Mayadrasha $\left(35 \pm 1 \mathrm{mg} \mathrm{kg}^{-1}\right)$ and Edagaarbi $\left(35 \pm 1 \mathrm{mg} \mathrm{kg}^{-1}\right)$ followed by Debrebirhan with $28 \pm 4 \mathrm{mg} \mathrm{kg}^{-1}$ of fenugreek seed per dry mass. However Cu was not detected at the Jehaniagiorgis sample site. The ESADDI for Cu for adults is 1.5-3 mg per day (WARDLAW, 1997). The three sample sites with the greatest Co concentrations were Hatsebo, Jehaniagiorgis and Edagaarbi with values of $15 \pm 0.4 \mathrm{mg} \mathrm{kg}^{-1}, 15 \pm 0.6 \mathrm{mg} \mathrm{kg}^{-1}$ and $14 \pm 0.7 \mathrm{mg} \mathrm{kg}^{-1}$, respectively, and that with the lowest Co concentration was Keteteekli, with $4 \pm 0.3 \mathrm{mg} \mathrm{kg}^{-1}$ per dry mass.

The Meseretgamra, Debrebirhan and Edagaarbi sites recorded the highst $\mathrm{Pb}$ concentrations when compared with the other sample sites, with $2624 \pm 101 \mathrm{mg} \mathrm{kg}^{-1}$, $1814 \pm 67 \mathrm{mg} \mathrm{kg}^{-1}$ and $1776 \pm 145 \mathrm{mg} \mathrm{kg}^{-1} \mathrm{~Pb}$ per dry mass, respectively, and the Bichena sample site showed the lowest $\mathrm{Pb}$ concentration $\left(422 \pm 42 \mathrm{mg} \mathrm{kg}^{-1}\right)$. The three highest $\mathrm{Cd}$ concentrations ( $464 \pm 14 \mathrm{mg} \mathrm{kg}^{-1}, 463 \pm 10 \mathrm{mg} \mathrm{kg}^{-1}$ and $396 \pm 10 \mathrm{mg} \mathrm{kg}^{-1}$ ) were recorded at the Dabat, Bichena and Keteteekli sample sites, respectively, whereas the sites at Adet and Meseretgamra recorded the lowest $\mathrm{Cd}$ concentrations of $285 \pm 22 \mathrm{mg} \mathrm{kg}^{-1}$ and $285 \pm 32 \mathrm{mg} \mathrm{kg}^{-1}$ per dry mass, respectively. Of all the metals determined in fenugreek seeds in this study, Co showed the lowest concentration with a mean value of Co $11 \mathrm{mg} \mathrm{kg}^{-1}$ per dry mass.

\subsection{Comparison of the metal concentrations found in fenugreek seeds in this study with the data found in the literature}

Table 2 shows the comparison between the metal contents found in the Ethiopian fenugreek samples with the data found in the literature. The Ca concentration found in fenugreek seed was highest in Ethiopia (26364 $\mathrm{mg} \mathrm{kg}^{-1}$ ) followed by Turkey $\left(2341 \pm 146 \mathrm{mg} \mathrm{kg}^{-1}\right)$, UAE $\left(84 \mathrm{mg} \mathrm{kg}^{-1}\right)$ 
Levels of essential and toxic metals in fenugreek seeds (Trigonella Foenum-Graecum L.) cultivated in different parts of Ethiopia

Hagos, M.; Chandravanshi, B. S.

Table 2. Comparison of the metal concentrations found in the fenugreek seeds used in this study with results found in the literature.

\begin{tabular}{|c|c|c|c|c|c|c|c|c|c|c|c|c|c|c|}
\hline \multirow{2}{*}{$\begin{array}{l}\text { Sample } \\
\text { origin }\end{array}$} & \multicolumn{13}{|c|}{ Concentration in $\mathbf{~ g ~} \mathbf{~ k g}^{-1}$} & \multirow{2}{*}{ Ref. } \\
\hline & $\mathrm{Ca}$ & K & $\mathrm{Na}$ & Mg & $\mathrm{Fe}$ & $\mathrm{Cr}$ & $\mathbf{N i}$ & $\mathbf{Z n}$ & Mn & $\mathrm{Cu}$ & Co & $\mathbf{P b}$ & Cd & \\
\hline India & - & - & - & - & - & 57310 & 31050 & 47150 & - & 1790 & 5610 & 4880 & 1770 & $\begin{array}{c}\text { (GIRISHA; } \\
\text { RAGAVENDRA, 2009) }\end{array}$ \\
\hline India & - & - & - & - & - & 56380 & 42250 & 65480 & - & 4280 & 9180 & 5620 & 1360 & $\begin{array}{c}\text { (GIRISHA; } \\
\text { RAGAVENDRA, 2009) }\end{array}$ \\
\hline Turkey & 2341 & - & - & 1373 & 62.6 & 0.6 & 2.1 & 54.6 & 15.9 & 9.4 & 0.41 & 0.4 & 0.13 & (KAN et al., 2005) \\
\hline Iran & - & - & - & - & 702 & 23.0 & - & 111 & 28.0 & - & - & - & - & (FATIMA et al., 2005) \\
\hline Egypt & - & - & - & - & - & - & - & 14.6 & - & 7.3 & - & 0.3 & 0.2 & $\begin{array}{c}\text { (SALAMA; } \\
\text { RADWAN, 2005) }\end{array}$ \\
\hline UAE & 84 & 18203 & 37280 & 168 & 588 & 1.8 & 3.0 & - & 48 & 0.14 & - & 0.25 & 0.30 & (KHAN, et al., 2006) \\
\hline Iran & - & - & - & - & 702 & 23.0 & - & 111 & 28.0 & - & - & - & - & (FATIMA et al., 2005) \\
\hline $\begin{array}{l}\text { Saudi } \\
\text { Arabia }\end{array}$ & 1.3 & 276 & 20.3 & - & 2.7 & - & - & 0.375 & - & 0.104 & - & 0.091 & 0.017 & (RANDHIR et al., 2004) \\
\hline Ethiopia & 26364 & 8448 & 744 & 69 & 14077 & 278 & 81 & 23 & 19 & 17 & 11 & 1330 & 344 & $\begin{array}{l}\text { This } \\
\text { study }\end{array}$ \\
\hline
\end{tabular}

and the lowest value in Saudi Arabia (1.28 $\mathrm{mg} \mathrm{kg}^{-1}$ ). The $\mathrm{K}$ concentration found in Ethiopia was intermediate (9120 $\mathrm{mg} \mathrm{kg}^{-1}$ ) between the $\mathrm{K}$ concentrations found in Saudi Arabia (272 $\mathrm{mg} \mathrm{kg}^{-1}$ ) and in UAE (18203 $\mathrm{mg} \mathrm{kg}^{-1}$ ). The $\mathrm{Na}$ concentration found in the fenugreek seeds in UAE (37280 $\mathrm{mg} \mathrm{kg}^{-1}$ ) was considerably higher than the concentrations found in Ethiopia (744 $\mathrm{mg} \mathrm{kg}^{-1}$ ) and in Saudi Arabia (20.3 $\mathrm{mg} \mathrm{kg}^{-1}$ ). The Mg concentration found in Ethiopia was the lowest (69 $\left.\mathrm{mg} \mathrm{kg}^{-1}\right)$ as compared to the concentrations found in UAE (168 $\left.\mathrm{mg} \mathrm{kg}^{-1}\right)$ and in Turkey $\left(1373 \pm 45 \mathrm{mg} \mathrm{kg}^{-1}\right)$.

The fenugreek seeds from Ethiopia contained the highest (14077 $\mathrm{mg} \mathrm{kg}^{-1}$ ) Fe concentration, probably due to the fact that the Ethiopian soils are rich in Fe minerals, e.g. $\mathrm{Fe}_{2} \mathrm{O}_{3}$. The second highest $\mathrm{Fe}$ concentration was found in the fenugreek seeds from Iran (702 $\left.\pm 30 \mathrm{mg} \mathrm{kg}^{-1}\right)$, followed by UAE (588 $\left.\mathrm{mg} \mathrm{kg}^{-1}\right)$, Turkey $\left(62.6 \pm 5.4 \mathrm{mg} \mathrm{kg}^{-1}\right)$ and the lowest value from Saudi Arabia, with only (2.74 $\mathrm{mg} \mathrm{kg}^{-1}$ ). The $\mathrm{Cr}$ concentrations found in India were much larger (56380-57310 $\mathrm{mg} \mathrm{kg}^{-1}$ ) than the others, followed by Ethiopia (278 $\left.\mathrm{mg} \mathrm{kg}^{-1}\right)$, Iran $\left(23.0 \pm 1.6 \mathrm{mg} \mathrm{kg}^{-1}\right), \mathrm{UAE}$ $\left(1.8 \mathrm{mg} \mathrm{kg}^{-1}\right)$ and the lowest concentration from Turkey, with $\left(0.64 \pm 0.29 \mathrm{mg} \mathrm{kg}^{-1}\right)$. The Ni concentration in fenugreek seed was also much greater in the Indian samples than in the others (31050-42250 $\left.\mathrm{mg} \mathrm{kg}^{-1}\right)$, followed by Ethiopia (18 $\left.\mathrm{mg} \mathrm{kg}^{-1}\right), \mathrm{UAE}\left(3.0 \mathrm{mg} \mathrm{kg}^{-1}\right)$ and the lowest recorded value in Turkey $\left(2.085 \pm 0.623 \mathrm{mg} \mathrm{kg}^{-1}\right)$. The highest $\mathrm{Zn}$ concentration was observed in India with a range from (47150-65480 $\left.\mathrm{mg} \mathrm{kg}^{-1}\right)$, followed by Iran $\left(111 \pm 13 \mathrm{mg} \mathrm{kg}^{-1}\right)$, Turkey $\left(54.6 \pm 5.2 \mathrm{mg} \mathrm{kg}^{-1}\right)$, Ethiopia ( $\left.23 \mathrm{mg} \mathrm{kg}^{-1}\right)$, Egypt $\left(14.6 \pm 4.6 \mathrm{mg} \mathrm{kg}^{-1}\right)$ and the lowest value in Saudi Arabia (23 $\mathrm{mg} \mathrm{kg}^{-1}$ ). The $\mathrm{Mn}$ concentration found in Ethiopian fenugreek seed was intermediate $\left(19 \mathrm{mg} \mathrm{kg}^{-1}\right)$ when compared to the others, the highest concentration being recorded in UAE (48 $\mathrm{mg} \mathrm{kg}^{-1}$ ) followed by Iran $\left(28.0 \pm 1.3 \mathrm{mg} \mathrm{kg}^{-1}\right)$, and the lowest value in Turkey with a concentration of $\left(15.9 \pm 1.4 \mathrm{mg} \mathrm{kg}^{-1}\right)$. The Cu concentration in the fenugreek seeds from India was far greater than in the others, with a range from (1790-4280 $\left.\mathrm{mg} \mathrm{kg}^{-1}\right)$, followed by Ethiopia (17 mg kg-1), Turkey $\left(9.4 \pm 1.3 \mathrm{mg} \mathrm{kg}^{-1}\right)$, Egypt $\left(7.25 \pm 0.29 \mathrm{mg} \mathrm{kg}^{-1}\right), \operatorname{UAE}\left(0.14 \mathrm{mg} \mathrm{kg}^{-1}\right)$ and the lowest value of $\left(0.104 \mathrm{mg} \mathrm{kg}^{-1}\right)$ from Saudi Arabia. Similarly the Co concentration in the Indian fenugreek seeds was much higher (5610-9180 $\mathrm{mg} \mathrm{kg}^{-1}$ ) than in Ethiopia (11 $\mathrm{mg} \mathrm{kg}^{-1}$ ) and Turkey $\left(0.413 \pm 0.067 \mathrm{mg} \mathrm{kg}^{-1}\right)$, and Co was not detected in the Saudi Arabian fenugreek seed.

The $\mathrm{Cd}$ concentration was highest in the Indian fenugreek seeds (1360-1770 $\mathrm{mg} \mathrm{kg}^{-1}$ ) followed by Ethiopia (344 mg kg-1), UAE (0.30 mg kg-1), Egypt $\left(0.15 \pm 0.11 \mathrm{mg} \mathrm{kg}^{-1}\right)$, and Turkey $\left(0.127 \pm 0.068 \mathrm{mg} \mathrm{kg}^{-1}\right)$, with the lowest value recorded in Saudi Arabia $\left(0.017 \mathrm{mg} \mathrm{kg}^{-1}\right)$. The $\mathrm{Pb}$ concentration was highest in India (5620-4880 $\mathrm{mg} \mathrm{kg}^{-1}$ ) followed by Ethiopia (1330 $\left.\mathrm{mg} \mathrm{kg}^{-1}\right)$, Turkey $\left(0.39 \pm 0.31 \mathrm{mg} \mathrm{kg}^{-1}\right)$, Egypt $\left(0.26 \pm 0.12 \mathrm{mg} \mathrm{kg}^{-1}\right)$, UAE $\left(0.25 \mathrm{mg} \mathrm{kg}^{-1}\right)$ and Saudi Arabia (ND-0.091 mg kg-1). However, the Indian fenugreek was grown in an industrially polluted area and treated with sludge water.

Thus the concentrations of the toxic metals $\mathrm{Cd}$ and $\mathrm{Pb}$ were higher in the Ethiopian fenugreek seed than in the fenugreek seeds from the other countries, except from India. Hence, the government or authorized bodies should make people aware of the risk of ingesting these metals from the regular intake of fenugreek seed in foods.

\subsection{Comparison of the metal concentrations found in fenugreek seeds with those found in other spices}

The metal concentrations determined in the fenugreek seeds were compared with the values found in other spices in Ethiopia (Table 3). These spices were red 
Levels of essential and toxic metals in fenugreek seeds (Trigonella Foenum-Graecum L.) cultivated in different parts of Ethiopia

Hagos, M.; Chandravanshi, B. S.

Table 3. Comparison of the metal concentrations found in fenugreek seed with the values found in other spices as reported, in the literature.

\begin{tabular}{|c|c|c|c|c|c|c|c|}
\hline \multirow{2}{*}{ Metal } & \multicolumn{7}{|c|}{ Concentration $\left(\mathrm{mg} \mathrm{kg}^{-1}\right)$ in different types of spice samples } \\
\hline & Fenugreek & Red pepper & Ginger & Korarima & Cardamom* & Fennel & Thyme \\
\hline $\mathrm{Ca}$ & $15353-36771$ & $161-222$ & $2000-2540$ & $1794-2181$ & $2719 \pm 35$ & $20500-23000$ & $1239-2776$ \\
\hline K & $6789-11517$ & $2378-2486$ & - & - & - & - & - \\
\hline $\mathrm{Na}$ & $201-1559$ & $75-93$ & - & - & - & - & - \\
\hline $\mathrm{Mg}$ & $31-102$ & - & $2700-4090$ & $1626-2067$ & $2390 \pm 41$ & $1310-3460$ & $1524-1786$ \\
\hline $\mathrm{Fe}$ & $6041-18584$ & $99.5-157$ & $41.8-89.0$ & $37.0-46.5$ & $64.8 \pm 2.2$ & $1140-1900$ & $728-2517$ \\
\hline $\mathrm{Cr}$ & $3-552$ & $27.5-73.6$ & $6.02-10.8$ & $3.8-5.8$ & $8.3 \pm 0.7$ & $90.9-97.7$ & - \\
\hline $\mathrm{Ni}$ & $31-108$ & $2.7-6.7$ & $5.61-8.40$ & $6.6-8.5$ & $11.7 \pm 0.5$ & $18.7-24.2$ & $9.83-14.2$ \\
\hline $\mathrm{Zn}$ & $15-33$ & $20.8-58.4$ & $38.5-55.2$ & $12-18$ & $19.6 \pm 0.9$ & $37.1-44.7$ & $8.7-52$ \\
\hline $\mathrm{Mn}$ & $16-28$ & $9.7-18.9$ & $184-401$ & $144-180$ & $355.4 \pm 9.8$ & $30.6-51.4$ & $37.7-114$ \\
\hline $\mathrm{Cu}$ & ND-35 & $2.1-3.7$ & $1.10-4.78$ & $5.8-8.3$ & $9.5 \pm 1.0$ & $23.9-103$ & $7.69-10.1$ \\
\hline Co & $4-15$ & $1.0-2.2$ & $2.04-7.58$ & $2.0-2.3$ & $2.6 \pm 0.2$ & $26.2-70.8$ & $2.59-4.50$ \\
\hline $\mathrm{Pb}$ & $615-1814$ & ND & - & ND & ND & ND & - \\
\hline $\mathrm{Cd}$ & $285-464$ & $0.20-0.23$ & $0.38-0.97$ & $0.9-1.0$ & $0.87 \pm 0.07$ & $1.59-1.91$ & $0.87-1.3$ \\
\hline Ref. & This study & $\begin{array}{l}\text { (TEFERA; } \\
\text { CHANDRA- } \\
\text { VANSHI, 2016) }\end{array}$ & $\begin{array}{l}\text { (WAGESHO; } \\
\text { CHANDRA- } \\
\text { VANSHI, 2015) }\end{array}$ & $\begin{array}{l}\text { (MEKASSA; } \\
\text { CHANDRA- } \\
\text { VANSHI, 2015) }\end{array}$ & $\begin{array}{l}\text { (MEKASSA; } \\
\text { CHANDRA- } \\
\text { VANSHI, 2015) }\end{array}$ & $\begin{array}{l}\text { (ENDALAMAW; } \\
\text { CHANDRA- } \\
\text { VANSHI, 2015) }\end{array}$ & $\begin{array}{l}\text { (DERBIE; } \\
\text { CHANDRA- } \\
\text { VANSHI, 2011) }\end{array}$ \\
\hline
\end{tabular}

${ }^{*}$ The values are the mean \pm SD. ND $=$ Not detected. $-=$ Not reported

pepper, ginger, korarima, cardamom, fennel and thyme. The highest $\mathrm{Ca}$ concentration was recorded in fenugreek seeds (15353-36771 $\mathrm{mg} \mathrm{kg}^{-1}$ ) and the lowest in red peppers (161-222 $\left.\mathrm{mg} \mathrm{kg}^{-1}\right)$. The decreasing order of the Ca concentrations in these spices was as follows: fenugreek seed $>$ fennel $>$ cardamom $>$ thyme $>$ ginger $>$ korarima $>$ red pepper. The $\mathrm{K}$ concentration in fenugreek seed was (6789-11517 $\mathrm{mg} \mathrm{kg}^{-1}$ ) and in red peppers (2378-2486 $\mathrm{mg} \mathrm{kg}^{-1}$ ) while its concentration was not reported in the other spices. The Na concentration in fenugreek seed was (201-1559 $\mathrm{mg} \mathrm{kg}^{-1}$ ) and in red peppers (75-93 $\mathrm{mg} \mathrm{kg}^{-1}$ ) and again its concentration was not reported in the other spices. The highest $\mathrm{Mg}$ concentration was observed in ginger (2700-4094 $\mathrm{mg} \mathrm{kg}^{-1}$ ) and the lowest in fenugreek seed (31-102 $\mathrm{mg} \mathrm{kg}^{-1}$ ) while its concentration was not reported in red peppers. The decreasing order for the concentration of $\mathrm{Mg}$ in these spices was as follows: ginger > fennel $>$ cardamom $>$ korarima $>$ thyme $>$ fenugreek seed.

The highest Fe concentration was recorded in fenugreek seed (6041-18584 $\mathrm{mg} \mathrm{kg}^{-1}$ ) and the lowest in korarima (37-46.5 $\mathrm{mg} \mathrm{kg}^{-1}$ ). The decreasing order for the concentration of $\mathrm{Fe}$ in these spices was as follows: fenugreek seed $>$ thyme $>$ fennel $>$ red pepper $>$ ginger $>$ cardamom $>$ korarima. The $\mathrm{Cr}$ concentration was highest (3-552 $\mathrm{mg} \mathrm{kg}^{-1}$ ) in fenugreek and lowest in korarima (3.8-5.8 $\mathrm{mg} \mathrm{kg}^{-1}$ ) and its concentration was not reported in thyme. The decreasing order for the concentration of $\mathrm{Cr}$ in these spices was as follows: fenugreek seed > fennel > red pepper > ginger > cardamom $>$ korarima. The highest Ni concentration was recorded in fenugreek seed (31-108 $\left.\mathrm{mg} \mathrm{kg}^{-1}\right)$ and the lowest in red peppers (2.7-6.7 $\mathrm{mg} \mathrm{kg}^{-1}$ ). The decreasing order for the concentration of $\mathrm{Ni}$ in these spices was as follows: fenugreek seed $>$ fennel $>$ thyme $>$ cardamom $>$ korarima $>$ ginger $>$ red pepper. The highest $Z n$ concentration was recorded in ginger (38.5-55.2 $\left.\mathrm{mg} \mathrm{kg}^{-1}\right)$ and the lowest in korarima (12-18 $\mathrm{mg} \mathrm{kg}^{-1}$ ) while the $\mathrm{Zn}$ concentration in fenugreek seed was between these two concentrations. The lowest Mn concentration in these spices was recorded in fenugreek seed (16-28 $\mathrm{mg} \mathrm{kg}^{-1}$ ) and the highest in ginger (184-401 $\mathrm{mg} \mathrm{kg}^{-1}$ ). The decreasing order for the Mn concentration in these spices was as follows: ginger $>$ cardamom $>$ korarima $>$ thyme $>$ fennel $>$ red pepper $>$ fenugreek seed. The highest $\mathrm{Cu}$ concentration was recorded in fennel (23.9-103 $\left.\mathrm{mg} \mathrm{kg}^{-1}\right)$ and the lowest in red peppers (2.1-3.7 $\mathrm{mg} \mathrm{kg}^{-1}$ ). The decreasing order for the concentration of $\mathrm{Cu}$ in these spices was as follows: fennel $>$ fenugreek $>$ thyme $>$ cardamom $>$ korarima $>$ ginger $>$ red pepper. The Co concentration was the highest in fennel (26.2-70.8 $\left.\mathrm{mg} \mathrm{kg}^{-1}\right)$ and the lowest in red peppers (1.0-2.2 $\left.\mathrm{mg} \mathrm{kg}^{-1}\right)$. and the Co concentration in fenugreek was between these two concentrations. The decreasing order for the concentration of $\mathrm{Co}$ in these spices was as follows: fennel > fenugreek > ginger $>$ thyme $>$ cardamom $>$ korarima $>$ red pepper.

However, the $\mathrm{Pb}$ concentration in fenugreek was very high (615-1814 $\mathrm{mg} \mathrm{kg}^{-1}$ ) whereas it was not detected in the other spices. Cd was studied in all the spices and the highest concentration was recorded in fenugreek (285-464 $\mathrm{mg} \mathrm{kg}^{-1}$ ) whilst the lowest was found in red peppers $\left(0.20-0.23 \mathrm{mg} \mathrm{kg}^{-1}\right)$. The decreasing order for the concentration of $\mathrm{Cd}$ in these spices was as follows: fenugreek $>$ fennel $>$ thyme $>$ korarima $>$ cardamom $>$ ginger $>$ red pepper.

\subsection{Analysis of variance}

ANOVA is an extremely powerful statistical technique which can be used to separate and estimate the different causes of variation (MILLER; MILLER, 2000). In this study 
Levels of essential and toxic metals in fenugreek seeds (Trigonella Foenum-Graecum L.) cultivated in different parts of Ethiopia

Hagos, M.; Chandravanshi, B. S.

a one way ANOVA was used with the help of the SPSS software program to compare the means of more than two groups of samples. ANOVA uses the F-test statistic to compare whether the differences between the sample means are significant or not (MILLER; MILLER, 2000).

In the present study Trigonella foenum-graecum L. (fenugreek seed) samples were collected from 14 different regions of Ethiopia and the metal levels of 13 metals determined using FAAS. However, the sample preparation and digestion process could result in random errors during the instrumental analysis. Therefore a one way ANOVA was used with the help of the SPSS software program to analyse the variance that could result from the differences in the metal contents of the soils from the different sample sites, the acidity of the soil, the atmospheric condition of the environment, water, fertilizers, etc.

Table 4 shows that all the sample means had significant differences at $F_{13,28}$ at a 95\% confidence level. Nevertheless, no significant difference was observed between the sample means in the case of $\mathrm{Zn}$. The significant differences in the means of the samples could be due to differences in the metal contents of the soils at these sample sites, the $\mathrm{pH}$ of the soils and the type of fertilizers used at these sites. However, the difference between the sample means for $Z n$ was not significant at $F_{13.28}$ for a $95 \%$ confidence level, most probably due to random errors in the analytical procedures and instrumental errors.

\subsection{Pearson's correlation for the metals in the fenugreek seed samples}

The product moment-correlation coefficient $(r)$ has values that range from $-1 \leq r \leq+1$. The $r$ value of -1 describes a perfect negative correlation, i.e. all the experimental points lie on a straight line with a negative slope. Similarly, the $r$ value of +1 describes a perfect positive correlation, all the points lying exactly on a straight line with a positive slope. However, a zero $r$ value does not mean that the two components (e.g. $y$ and $x$ in the formula) are entirely unrelated; it only means that they are not linearly related (MILLER; MILLER, 2000). Table 5 shows the values obtained for the correlation coefficients between the metal concentrations found in the fenugreek seed samples. The fenugreek seed metal vs. fenugreek seed metal system showed good positive correlations for $\mathrm{Na}-\mathrm{Pb}, \mathrm{Mn}-\mathrm{Co}$ and $\mathrm{Fe}-\mathrm{K}$ with corresponding $\mathrm{r}$ values of $0.659,0.521$ and 0.526 , respectively. However, an inverse

Table 4. Analysis of variance between and within samples of fenugreek seed samples at a 95\% confidence level.

\begin{tabular}{|c|c|c|c|c|c|}
\hline Metal & Comparison & Df & $\mathbf{F}_{\text {calculated }}$ & $F_{\text {critical }}$ & Remark \\
\hline \multirow{2}{*}{$\mathrm{Ca}$} & Between Groups & 13 & \multirow{2}{*}{14.1} & \multirow{2}{*}{1.75} & \multirow{2}{*}{ Significant difference between sample means } \\
\hline & Within Groups & 28 & & & \\
\hline \multirow{2}{*}{ K } & Between Groups & 13 & \multirow{2}{*}{97.6} & \multirow{2}{*}{1.75} & \multirow{2}{*}{ Significant difference between sample means } \\
\hline & Within Groups & 28 & & & \\
\hline \multirow{2}{*}{$\mathrm{Na}$} & Between Groups & 13 & \multirow{2}{*}{8.87} & \multirow{2}{*}{1.75} & \multirow{2}{*}{ Significant difference between sample means } \\
\hline & Within Groups & 28 & & & \\
\hline \multirow{2}{*}{$\mathrm{Mg}$} & Between Groups & 13 & \multirow{2}{*}{39.5} & \multirow{2}{*}{1.75} & \multirow{2}{*}{ Significant difference between sample means } \\
\hline & Within Groups & 28 & & & \\
\hline \multirow{2}{*}{$\mathrm{Fe}$} & Between Groups & 13 & \multirow{2}{*}{3.95} & \multirow{2}{*}{1.75} & \multirow{2}{*}{ Significant difference between sample means } \\
\hline & Within Groups & 28 & & & \\
\hline \multirow{2}{*}{$\mathrm{Cr}$} & Between Groups & 13 & \multirow{2}{*}{12.5} & \multirow{2}{*}{1.75} & \multirow{2}{*}{ Significant difference between sample means } \\
\hline & Within Groups & 28 & & & \\
\hline \multirow{2}{*}{$\mathrm{Ni}$} & Between Groups & 13 & \multirow{2}{*}{18.9} & \multirow{2}{*}{1.75} & \multirow{2}{*}{ Significant difference between sample means } \\
\hline & Within Groups & 28 & & & \\
\hline \multirow{2}{*}{$\mathrm{Zn}$} & Between Groups & 13 & \multirow{2}{*}{1.57} & \multirow{2}{*}{1.75} & \multirow{2}{*}{ No Significant difference between sample means } \\
\hline & Within Groups & 28 & & & \\
\hline \multirow{2}{*}{$\mathrm{Mn}$} & Between Groups & 13 & 361 & 175 & Sianificant difference hetweon camnle meanc \\
\hline & Within Groups & 28 & 30.1 & 1.15 & signimcant anterence oetween sample means \\
\hline & Between Groups & 13 & 101 & $175,7>3$ & n camplo moanc \\
\hline $\mathrm{Cu}$ & Within Groups & 28 & 194 & 1.15 & Signiticant dıtterence between sample means \\
\hline$\Omega_{0}$ & Between Groups & 13 & 132 & 175 & Sianificont difforonge hotwon complo mornc \\
\hline CO & Within Groups & 28 & 43.2 & 1.15 & signiticant altierence between sample means \\
\hline $\mathrm{Ph}$ & Between Groups & 13 & 603 & 175 & Sianificant difference between samnle means \\
\hline & Within Groups & 28 & & & \\
\hline $\mathrm{Cg}$ & Between Groups & 13 & 315 & 175 & Sianificant difference between samole means \\
\hline Ca & Within Groups & 28 & & & \\
\hline
\end{tabular}

Df is degree of freedom. 
Levels of essential and toxic metals in fenugreek seeds (Trigonella Foenum-Graecum L.) cultivated in different parts of Ethiopia

Hagos, M.; Chandravanshi, B. S.

Table 5. Pearson's correlation of the fenugreek seed metals vs. fenugreek seed metals system.

\begin{tabular}{|c|c|c|c|c|c|c|c|c|c|c|c|c|c|}
\hline & $\mathrm{Ca}$ & $\mathrm{K}$ & $\mathrm{Na}$ & Mg & $\mathrm{Fe}$ & $\mathrm{Cr}$ & $\mathrm{Ni}$ & $\mathbf{Z n}$ & Mn & $\mathrm{Cu}$ & Co & $\mathbf{P b}$ & Cd \\
\hline $\mathrm{Ca}$ & 1.000 & & & & & & & & & & & & \\
\hline K & 0.158 & 1.000 & & & & & & & & & & & \\
\hline $\mathrm{Na}$ & 0.313 & 0.215 & 1.000 & & & & & & & & & & \\
\hline $\mathrm{Mg}$ & 0.109 & 0.182 & 0.140 & 1.000 & & & & & & & & & \\
\hline $\mathrm{Fe}$ & 0.203 & 0.526 & 0.342 & 0.123 & 1.000 & & & & & & & & \\
\hline $\mathrm{Cr}$ & 0.080 & 0.252 & -0.698 & -0.334 & 0.043 & 1.000 & & & & & & & \\
\hline $\mathrm{Ni}$ & -0.062 & 0.146 & 0.179 & 0.153 & 0.021 & -0.253 & 1.000 & & & & & & \\
\hline $\mathrm{Zn}$ & 0.047 & -0.386 & -0.237 & -0.066 & -0.108 & 0.133 & -0.177 & 1.000 & & & & & \\
\hline $\mathrm{Mn}$ & -0.491 & -0.252 & -0.291 & -0.208 & -0.151 & -0.128 & -0.147 & 0.204 & 1.000 & & & & \\
\hline $\mathrm{Cu}$ & 0.292 & 0.220 & 0.405 & -0.032 & 0.315 & -0.192 & -0.348 & 0.125 & 0.336 & 1.000 & & & \\
\hline Co & 0.105 & 0.160 & 0.010 & -0.072 & 0.230 & -0.163 & 0.251 & 0.038 & 0.521 & 0.472 & 1.000 & & \\
\hline $\mathrm{Pb}$ & 0.106 & 0.191 & 0.659 & -0.127 & -0.011 & -0.475 & -0.299 & -0.458 & -0.086 & 0.448 & 0.035 & 1.000 & \\
\hline $\mathrm{Cd}$ & 0.025 & -0.026 & -0.319 & 0.081 & -0.021 & 0.391 & -0.122 & -0.040 & -0.126 & -0.376 & -0.179 & 0.320 & 1.000 \\
\hline
\end{tabular}

relationship occurred between $\mathrm{Na}$ and $\mathrm{Cr}(-0.698)$. All the other relationships showed weak positive or negative linear relationships, which implies that the presence of one metal did not affect the presence of the other metal within the plant.

\section{Conclusions}

The levels of the major ( $\mathrm{Ca}, \mathrm{K}, \mathrm{Na}, \mathrm{Mg}$ ), trace (Fe, Cr, Ni, Zn, Mn, Cu, Co) and toxic (Pb, Cd) metals in Trigonella foenum-graecum L. (fenugreek seed) grown in different parts of Ethiopia, were determined by flame atomic absorption spectrometry.

The levels of these metals were found in the following ranges and order in the fenugreek seeds; $\mathrm{Ca}$ $\left(15353-36771 \mathrm{mg} \mathrm{kg}^{-1}\right)>\mathrm{Fe}\left(6041-18584 \mathrm{mg} \mathrm{kg}^{-1}\right) \approx \mathrm{K}$ $\left(6789-11517 \mathrm{mg} \mathrm{kg}^{-1}\right)>\mathrm{Pb}\left(615-2624 \mathrm{mg} \mathrm{kg}^{-1}\right)>\mathrm{Na}$ $\left(201-1559 \mathrm{mg} \mathrm{kg}^{-1}\right)>\mathrm{Cd}\left(285-464 \mathrm{mg} \mathrm{kg}^{-1}\right)>\mathrm{Cr}\left(3-552 \mathrm{mg} \mathrm{kg}^{-1}\right)$ $>\mathrm{Ni}\left(31-108 \mathrm{mg} \mathrm{kg}^{-1}\right)>\mathrm{Mg}\left(31-102 \mathrm{mg} \mathrm{kg}^{-1}\right)>\mathrm{Zn}(15-33$ $\left.\mathrm{mg} \mathrm{kg}{ }^{-1}\right)>\operatorname{Mn}\left(16-28 \mathrm{mg} \mathrm{kg}^{-1}\right)>\mathrm{Cu}\left(\mathrm{ND}-35 \mathrm{mg} \mathrm{kg}^{-1}\right)>$ Co (4-15 mg kg-1). The result of this study shows that the fenugreek seeds cultivated in Ethiopia are rich in all the above mentioned essential and toxic metals. The one-way ANOVA results at a 95\% confidence level showed that there were significant differences amongst the mean concentrations of all the metals with the exception of $\mathrm{Zn}$. This result can be attributed to differences in the $\mathrm{pH}$ of the soils, mineral composition of the soils and type of fertilizers used. Furthermore, Pearson's correlation coefficient ( $r$ ) was determined and used to correlate the metal concentrations amongst the fenugreek seed samples via the metal level vs. metal level system, and except for a few cases, most showed weak positive or negative linear relationships, indicating that the presence of one metal in the plant did not influence the presence of the other.

Fenugreek seed has many benefits for both producers and consumers in Ethiopia. However, some of the very toxic elements were found in high concentrations in this study, e.g. $\mathrm{Pb}$ and $\mathrm{Cd}$, and the prolonged accumulation of heavy metals ingested via foodstuffs may lead to chronic effects on the kidney and liver of humans and cause the disruption of numerous biochemical processes, leading to cardiovascular, nervous, kidney and bone diseases. Therefore, government organs and other concerned bodies should strengthen the studies of metal levels in most of the widely used spices and herbal medicines.

\section{Acknowledgements}

The authors express their gratitude to the Department of Chemistry, Addis Ababa University, Ethiopia, for providing the laboratory facilities. Mebrahtu Hagos gratefully acknowledges the financial support received from the Abiyi Addi College of Teacher Education, Ethiopia.

\section{References}

AHARI, D. S.; KASHI, A. K.; HASSANDOKHT, M. R.; AMRI, A.; ALIZADEH, K. Assessment of drought tolerance in Iranian fenugreek landraces. Journal of Food Agriculture and Environment, Helsinki, v. 7, p. 414-419, 2009.

ASFAW, N.; DEMISSEW, S. Aromatic plants of Ethiopia. Addis Ababa: Shama Books, 2009. p. 98-99.

BEKELE, E. Study on actual situation of medicinal plants in Ethiopia. Tokyo: Japan Association for International Collaboration of Agriculture and Forestry, 2007. p. 1-73. (v. 1).

CHANDRASHEKHAR, D.; KHADSE, B. K. In vivo anthelmintic activity of fenugreek seeds extract against Phertima postthuma. International Journal of Research in Pharmaceutical Sciences, Madurai, v. 1, p. 267-269, 2010.

DEMAN, J. M. Principles of food chemistry. 3rd ed. Maryland: Aspen Publishers, 1999. p. 209-223. 
Levels of essential and toxic metals in fenugreek seeds (Trigonella Foenum-Graecum L.) cultivated in different parts of Ethiopia

Hagos, M.; Chandravanshi, B. S.

DERBIE, A.; CHANDRAVANSHI, B. S. Concentration levels of selected metals in the leaves of different species of thyme ( $T$. schimperi and T. vulgaris) grown in Ethiopia. Biological Trace Element Research, London, v. 141, n. 1-3, p. 317-328, 2011. PMid:2049a9204. http://dx.doi.org/10.1007/s12011-010-8732-z.

EIBEN, C.; RASHWAN, A. A.; KUSTOS, K.; GÓDOR-SURMANN, K.; SZENDRÖ, Z. Effect of anise and fenugreek supplementation on performance of rabbit does. In: WORLD RABBIT CONGRESS, 8., 2004, Puebla. Proceedings... Castanet-Tolosan: World Rabbit Science Association, 2004. p. 805-810.

ENDALAMAW, F. D.; CHANDRAVANSHI, B. S. Levels of major and trace elements in fennel (Foeniculum vulgari Mill.) fruits cultivated in Ethiopia. SpringerPlus, Switzerland, v. 4, n. 1, p. 5 , 2015. PMid:25674492. http://dx.doi.org/10.1186/2193-1801-4-5.

ENKE, C. G. The art and science of chemical analysis. 2nd ed. New York: John Wiley and Sons, 2000.

EUROPEAN FOOD SAFETY AUTHORITY - EFSA. Conclusion on the peer review of pesticide risk assessement of the active substance fenugreek seed powder (FEN 560). European Food Safety Authority Journal, Parma, v. 8, p. 1-50, 2010.

EUROPEAN FOOD SAFETY AUTHORITY - EFSA. Panel on Dietetic Products, Nutrition and Allergies. Scientific opinion on dietary reference values for chromium. European Food Safety Authority, Parma, v. 12, n. 10, p. 1-25, 2014. http://dx.doi. org/10.2903/j.efsa.2014.3845.

FATIMA, N.; MAQSOOD, Z. T.; KHAN, B. Study of some micronutrients in selected medicinal plants. Scientica Iranica, Tehran, v. 12, p. 269-273, 2005.

GIRISHA, S. T.; RAGAVENDRA, V. B. Accumulation of heavy metals in leafy vegetables grown in urban areas by using sewage water and its effect. Archives of Phytopathology and Plant Protection, London, v. 42, n. 10, p. 956-959, 2009. http://dx.doi. org/10.1080/03235400701543806.

HEDBERG, I.; EDWARDS, S. Flora of Ethiopia: Pittosporaceae to Araliaceae. Addis Ababa: EMPDA, 1989. 246 p.

HOODA, S.; JOOD, S. Effect of fenugreek flour blending on physical, organoleptic and chemical characteristics of wheat bread. Nutrition \& Food Science, London, v. 35, n. 4, p. 229-242, 2005. http://dx.doi.org/10.1108/00346650510605621.

IBRAHIUM, M. I.; HEGAZY, A. I. Iron bioavailability of wheat biscuit supplemented by fenugreek seed flour. World Journal of Agricultural Sciences, Dubai, v. 5, p. 769-776, 2009.

JENNIFER, J. O.; JENNIFER, P. H.; LINDA, D. M. Dietary reference intakes: the essential guide to nutrient requirements. Washington: The National Academic Press, 2006. p. 370-422.

KAN, Y.; KAN, A.; CEYHAN, T.; SAYAR, E.; KARTAL, M.; ALTUN, L.; ASLAN, S.; CEVHEROĐLU, S. Atomic absorption spectrometric analysis of Trigonella foenum-graecum $\mathrm{L}$. seeds cultivated in
Turkey. Turkish Journal of Pharmaceutical Science, Ankara, v. 2, p. 187-191, 2005.

KHAN, S. A.; AHMAD, I.; MOHAJIR, M. S. Evaluation of mineral contents of some edible medicinal plants. Pakistan Journal of Pharmaceutical Sciences, Karachi, v. 19, n. 2, p. 141-148, 2006. PMid:16751127.

LEIGH BROADHURST, C. Nutrition and non-insulin dependent diabetes mellitus from an anthropological perspective. Alternative Medicine Review, Napa, v. 2, p. 378-399, 1997.

MARZOUGUI, N.; GUASMI, F.; BOUBAYA, A.; ELFALLEH, W.; LACHIEHEB, B.; FERCHICHI, A.; BEJI, M. Assessment of Tunisian Trigonella foenum-graecum diversity using physiological parameters. Journal of Food Agriculture and Environment, Helsinki, v. 7, p. 427-431, 2009.

MEKASSA, M.; CHANDRAVANSHI, B. S. Levels of selected essential and non-essential metals in seeds of korarima (Aframomum corrorima) cultivated in Ethiopia. Brazilian Journal of Food Technology, Campinas, v. 18, n. 2, p. 102-111, 2015. http:// dx.doi.org/10.1590/1981-6723.5614.

MILLER, J. N.; MILLER, J. C. Statistics and chemometrics for analytical chemistry. 4th ed. Great Britain: Pearson Pentice Hall, 2000.

RANDHIR, R.; LIN, Y.; SHETTY, K. Phenolics, their antioxidant and antimicrobial activity in dark germinated fenugreek sprouts in response to peptide and phytochemical elicitors. Asia Pacific Journal of Clinical Nutrition, London, v. 13, n. 3, p. 295-307, 2004. PMid: 15331344

SALAMA, A. K.; RADWAN, M. A. Heavy metals $(\mathrm{Cd}, \mathrm{Pb})$ and trace elements ( $\mathrm{Cu}, \mathrm{Zn}$ ) contents in some foodstuffs from the Egyptian market. Emirates Journal of Agricultural Sciences, Al Ain, v. 17, n. 1, p. 34-42, 2005. http://dx.doi.org/10.9755/ejfa.v12i1.5046.

SKOOG, D. A.; WEST, D. M.; HOLLER, F. J. Fundamentals of analytical chemistry. 7th ed. Orlando: Thomsons learning Inc., 1996. 736 p.

SOYLAK, M.; TUZEN, M.; NARIN, I.; SARI, H. Comparison of microwave, dry and wet digestion procedures for determination of trace metal contents in spice samples produced in Turkey. Journal of Food and Drug Analysis, New Taipei, v. 12, p. 254-258, 2004.

SUSHMA, N.; DEVASENA, T. Aqueous extract of Trigonella foenum graecum (fenugreek) prevents cypermethrin-induced hepatotoxicity and nephrotoxicity. Human and Experimental Toxicology, London, v. 29, n. 4, p. 311-319, 2010. PMid:20147568. http://dx.doi.org/10.1177/0960327110361502.

TEFERA, M.; CHANDRAVANSHI, B. S. Assessment of metal contents in commercially available Ethiopian red pepper. International Food Research Journal, Selangor, 2016. In press.

WAGESHO, Y.; CHANDRAVANSHI, B. S. Levels of essential and non-essential metals in ginger (Zingiber officinale) cultivated in 
Levels of essential and toxic metals in fenugreek seeds (Trigonella Foenum-Graecum L.) cultivated in different parts of Ethiopia

Hagos, M.; Chandravanshi, B. S.

Ethiopia. SpringerPlus, Switzerland, v. 4, n. 1, p. 107, 2015. PMid:25789209.http://dx.doi.org/10.1186/s40064-015-0899-5.

WARDLAW, G. M. Contemporary nutrition. 3rd ed. Madison: WCB/McGraw-Hill, 1997. p. 330-332.
ZIA, T.; SIDDIQUI, I. A.; SHAUKAT, S. S.; NAZARUL-HASNAIN, S. Trigonella foenum- graecum (fenugreek) - mediated suppression of meloidogyne javanica in mungbean. Archives of Phytopathology and Plant Protection, London, v. 36, n. 1, p. 23-31, 2003. http:// dx.doi.org/10.1080/0323540031000080164. 